\title{
Number of pregnancies and season of calving influence the production and reproduction traits in Nili-Ravi buffalo
}

\author{
Dhandapani S', Vikas Vohra' ${ }^{1}$, Supriya Chhotaray', Sanjay Kumar², KPSingh ${ }^{2}$ and RS Kataria $^{3}$
}

Received: 06 July 2020 / Accepted: 13 August 2020 / Published online: 27 October 2020

(C) Indian Dairy Association (India) 2020

\begin{abstract}
Production and reproduction traits in Nili-Ravi buffaloes maintained at the ICAR-Central Institute for Research on Buffaloes, Sub-campus, Nabha, Punjab, were analysed to study the impact of Number of pregnancies (parity) and season of birth on performance. The least squares method was used to elucidate the effect of parity and season on production and reproduction traits. The overall least squares means of production traits, 305 days or less milk yield, total lactation milk yield, and lactation length were $2603.22 \pm 47.66 \mathrm{~kg}, 2691.82 \pm 56.20 \mathrm{~kg}$, and $305.72 \pm 4.95$ days, respectively, and reproduction traits age at service, age at calving, service period, calving interval and dry period were $1418.76 \pm 16.60$ days, $1741.30 \pm 18.52$ days, $163.52 \pm 7.33$ days, $466.55 \pm 6.70$ days and $157.11 \pm 4.18$ days, respectively. The parity had shown significant effect on all studied production and reproduction traits. However, the season impacted only dry period in Nili-Ravi buffaloes.
\end{abstract}

Keywords: Nili-Ravi, Parity, Production traits, Reproduction traits, Season of calving.

\section{Introduction}

India is blessed with wealthy pool of buffalo genetic resources and world's superior buffalo breeds are native to India. Presently, there are 17 registered breeds of buffalo in India (ICAR-NBAGR, 2020) and among these identified buffalo breeds, the best breeds

\footnotetext{
${ }^{1}$ AGB Division, ICAR-National Dairy Research Institute, Karnal 132001 (Haryana), India

${ }^{2}$ ICAR-Central Institute for Research on Buffaloes, Hisar - 125001 (Haryana), India

${ }^{3}$ ICAR-National Bureau of Animal Genetic Resources, Karnal -132001 (Haryana), India

Vikas Vohra $(\square)$

AGB Division, ICAR-National Dairy Research Institute, Karnal - 132 001 Haryana, India

Email: vohravikas@gmail.com
}

maintained for milk production are Murrah, Nili-Ravi, Mehsana, and Jaffarabadi. The Nili-Ravi is one of the best riverine breeds of buffalo having its breeding region in Amritsar and Tarn-Taran areas of Punjab. Animals have black colour of skin, walled eyes and characteristic white markings are seen on the forehead, face, muzzle, feet, and tail and are considered the typical features of Nili Ravi breed of buffalo. The pure 'Panch Kalyani' (with allwhite extremities) has a beautiful appearance, and the breed has a good production and reproduction potential, despite of this, the breed has a limited breeding region in the North of India. The probable reason could be the market and breeders' preference for Murrah breed over the Nili-Ravi breed. It is interesting to note that while a population of pure Nili breed has been decreasing, despite the fact that its milk production is not lower than that of the Murrah. The quality of milk production and reproduction traits in Nili-Ravi are thought to be similar to an average breed of Murrah buffalo and is regarded to be superior in reproduction than Murrah (Vij and Tantia, 2005).

Production and reproduction is the significant economic trait and governs the economics of the dairying. The production and reproduction traits may be influenced by several factors which can be either genetic or non-genetic in nature. Variations in the environment may have great influence than the genetic components of variances (Price et al. 1991). Different non-genetic factors like season of calving, parity, period of calving, nutrition, temperature, services per conception, milking frequency, udder diseases, reproductive problems, housing and management conditions of the farm may masks the expression of precise genetic potential in the animals (Cunha et al. 2008). There are limited studies and scanty literature available which can indicate or identify the most important factor(s) influencing the performance in Nili-Ravi buffalo. Thus, it becomes imperative to identify important factors affecting the performance, so that an accurate estimate of genetic merit could be made in the Nili-Ravi breed of buffalo. With this knowledge, present study has been aimed to find out the effect of number of pregnancies (parity) and season of calving on various production and reproduction performance in the Nili-Ravi buffalo. 


\section{Materials and Methods}

\section{Sample size and performance traits}

The present study has been conducted at the ICAR-Central Institute for Research on Buffaloes, (sub campus-Nabha farm), Patiala, Punjab situated at 212 meters above mean sea level (29.17 N \& 75.72 E). About 214 Nili-Ravi buffaloes sired by 23 bulls and 90 dams across different parity and from the period of 2010 to 2015 were included in the study.

The performance traits have been classified as production and reproduction traits. Production traits included in the study were standard 305 days or less milk yield, total lactation milk yield, and lactation length and reproduction traits were age at service, age at calving, service period, calving interval, and dry period. All the lactations were clustered and finally 214 observations has taken for the study. The normal lactation was considered as a period of milk production by a cow for at least 100 days, the milk production in lactation has recorded a minimum of $500 \mathrm{~kg}$ and buffaloes without having the abortions, still birth, delayed calving and other reproductive disorders has been included in the study.

\section{Statistical model and analysis}

According to the number of calving the animals have been classified and coded into three groups, namely, first parity, second parity, and third and above parity. Depending on the type of feed and fodder availability in the farm and prevailing climatic conditions in the region as recorded in CIRB, Nabha farm, Patiala district of Punjab, the year was classified and coded into three seasons of calving, viz. summer (April to June), rainy (July to October), winter (November to March). The effect of non-genetic factors on production and reproduction traits were estimated by least-squares analysis of variance with the help of LSMLMW PC-2 VERSION software package (Harvey, 1990). The model was used with the assumptions that different components being fitted into the model are linear, independent, and additive. The Model for production and reproduction traits of all lactation is described as under
Model: $\quad \mathrm{Y}_{\mathrm{jkl}}=\mu+\mathrm{S}_{-\mathrm{j}}+\mathrm{P}_{\mathrm{k}}+\mathrm{e}_{\mathrm{jk} \mathrm{l}}$

Where,

$\mathrm{Y}_{\mathrm{jk} 1}=$ observation on $1^{\text {th }}$ buffalo of $\mathrm{k}^{\text {th }}$ parity in $\mathrm{j}^{\text {th }}$ season of calving of the animal

$\mu=$ Overall mean

$S_{j}=$ Fixed effect of $j^{\text {th }}$ season of calving $(j=1-3)$

$\mathrm{P}_{\mathrm{k}}=$ Fixed effect of $\mathrm{k}^{\text {th }}$ animals parity $(\mathrm{k}=1-3)$

$\mathrm{e}_{\mathrm{jkl}}=$ Random error NID $\sim\left(0, \sigma^{2} \mathrm{e}\right)$

The difference of means between any two subclasses of parity and season was tested for significance using Duncan's multiple range test (DMRT) as modified by Kramer (1957).

\section{Results and Discussion}

\section{Standard 305 days or less milk yield (S305DMY)}

The milk production of a buffalo is a result of the interplay between heredity and the environment. For improved accuracy of selection, it is important that the records reflect as precisely as possible the practical genetic potential for milk yield. The actual records themselves may be a poor indicator of breeding values since many environmental factors have marked effect on a NiliRavi buffalo's performance during any lactation. In order to check the actual milk production potential of the Nili-Ravi buffalo this trait has been analysed. The MSS value and analysis of variance for production and reproduction traits in Nili-Ravi buffalo are depicted in Table 1 and 2.

The overall least squares means of 305 days or less milk yield in Nili-Ravi buffalo was estimated as $2603.22 \pm 47.66 \mathrm{~kg}$, (Table 3). Lower estimates of standard 305 days or less milk yield than the present study were reported by Hussain et al. (2006) as $2191.858 \pm 35.353 \mathrm{~kg}$, Ahmad (2008) as $2030.13 \pm 14.58 \mathrm{~kg}$, and Chaudhary (2015) as $1913.87 \pm 133.61 \mathrm{~kg}$ in Nili-Ravi buffaloes.

Table 1 Analysis of variance (M.S.S Values) of production traits in Nili-Ravi buffalo

\begin{tabular}{llll}
\hline Source of variation & $\begin{array}{l}\text { 305 days } \\
\text { or less milk yield }\end{array}$ & $\begin{array}{l}\text { Total lactation } \\
\text { milk yield }\end{array}$ & Lactation length \\
\hline Parity & $2359470.62^{* *}$ & $1237182.22^{*}$ & $23946.82^{* *}$ \\
Season & 211826.11 & 160049.87 & 675.66 \\
\hline
\end{tabular}

Table 2 Analysis of variance (M.S.S Values) of reproduction traits in Nili-Ravi buffalo

\begin{tabular}{llllll}
\hline $\begin{array}{l}\text { Source of } \\
\text { variation }\end{array}$ & Age at service & Age at calving & Service period & Calving interval & Dry period \\
\hline Parity & $17997975.86^{* *}$ & $15849399.38^{* *}$ & $20041.15^{*}$ & $17137.50^{*}$ & \\
Season & 9144.95 & 7743.13 & 4533.54 & 3328.41 & $6639.11^{*}$ \\
\hline
\end{tabular}

** $(p<0.01)$, and* $(p<0.05)$ 
This indicates that over a period of last 10-15 years the performance at Nili-Ravi herd had improved, indicating the superior milch potential of the breed.

Parity has significant effect on standard 305 days or less milk yield $(\mathrm{p}<0.01)$. Maximum S305DMY was observed in second parity $(2725.72 \pm 75.71 \mathrm{~kg})$ and minimum S305DMY was observed in first parity $(2394.11 \pm 57.50)$.

Season of calving had shown non-significant effect on of standard 305 days or less lactation milk yield. The S305DMY in Nili-Ravi buffalo for summer, rainy, and winter season were estimated as $2554.52 \pm 105.31 \mathrm{~kg}, 2669.11 \pm 51.03 \mathrm{~kg}$, and $2586.03 \pm 66.70 \mathrm{~kg}$, respectively. Standard 305 days or less lactation milk yield was the highest in rainy season being a favourable season for production as well as reproduction, as ample supply of grasses and good quality fodder is available.

\section{Total lactation milk yield}

The overall least squares means of total lactation milk yield in Nili-Ravi buffalo was estimated as $2691.82 \pm 56.20 \mathrm{~kg}$, (Table 3). Lower estimates of total lactation milk yield than the present study were obtained by many workers. The overall least square mean for total lactation milk yield in Nili-Ravi buffalo were reported by Khan and Chaudhry (2000) as 1984 kg, Manzoor et al. (2003) as $1774 \pm 25.4 \mathrm{~kg}$, Afzal et al. (2007) as $1831.6 \pm 530.9 \mathrm{~kg}$, Khan et al. (2007) as $1984.4 \pm 773.43 \mathrm{~kg}$, Ahmad (2008) as $2462.92 \pm 195.93 \mathrm{~kg}$, Bashir et al. (2015) as $1840 \pm 8.0 \mathrm{~kg}$, Charlini and sinniah (2015) as $1187 \pm 543 \mathrm{~kg}$, Chaudhary (2015) as $1941.44 \pm 148.19 \mathrm{~kg}$, and which suggests the lower production than the present study.

The parity had shown a significant effect $(\mathrm{p}<0.05)$ on total lactation milk yield. Maximum milk yield was obtained in the second parity $(2802.92 \pm 89.28 \mathrm{~kg})$ and Minimum milk yield was obtained in the third and above parity $(2726.08 \pm 96.50 \mathrm{~kg})$. Significant influence of parity on total lactation milk yield was reported by Khan and Chaudhry (2000), Afzal et al. (2007), Khan et al. (2007), and Chaudhary (2015) in Nili-Ravi buffaloes.

Season of calving had non-significant effect on total lactation milk yield. The least-squares mean for total lactation milk yield in Nili-Ravi buffalo for summer, rainy, and winter season were estimated as $2650.25 \pm 124.18 \mathrm{~kg}, 2748.99 \pm 60.18 \mathrm{~kg}$, and $2676.22 \pm 78.66 \mathrm{~kg}$, respectively. Significant influence of season of calving on total lactation milk yield was reported by Khan and Chaudhry (2000), Manzoor et al. (2003), Khan et al. (2007), Afzal et al. (2007), Bashir et al. (2015). However, such effect could not be observed in the present study while non-significant effect on season calving reported by Chaudhary (2015) and Ghaffar et al. (1991) in Nili-Ravi buffaloes. Variable milk yield lead to the assumption that environmental factors, seasonal differences, type of feed, flood, draught, heavy rains, ambient temperature, humidity and level of management affects the production and reproduction traits. Management is bound to differ depending on the farm manager's capacity, his efficiency in staff supervision, his system of crop husbandry methods and the frequency of culling/ replacement in the herd.

\section{Lactation length}

The period from the date of calving to the date of the last milking is termed as lactation length. In addition to lactation days, maximum daily yield also governs the lactation length. In tropical countries environmental factors may affects the lactation length to the maximum extent. Higher lactation length around indicates the milch potential of the animals and longer peak milk yield is maintained in the more persistent buffaloes.

The overall least squares means of lactation length in Nili-Ravi buffalo was estimated as $305.72 \pm 4.95$ days (Table 3 ). Lower estimates of least squares mean of lactation length than present study were obtained by Khan and Chaudhry (2000) as 289.5 days, Afzal et al. (2007) as $273.3 \pm 52.8$ days, Khan et al. (2007) as

Table 3 Least squares mean with standard error of different production traits in Nili-Ravi buffalo

\begin{tabular}{llll}
\hline Traits & 305 days or less milk yield & Total lactation milk yield & Lactation length \\
\hline Overall $(\mu)$ & $2603.22 \pm 47.66(214)$ & $\begin{array}{c}2691.82 \pm 56.20(214) \\
\text { Parity }\end{array}$ & $305.72 \pm 4.95(214)$ \\
First parity & $2394.11^{\mathrm{a}} \pm 57.50(113)$ & $2546.46^{\mathrm{a}} \pm 67.80(113)$ & $324.28^{\mathrm{a}} \pm 5.98(113)$ \\
Second parity & $2725.72^{\mathrm{b}} \pm 75.71(54)$ & $2802.92^{\mathrm{b}} \pm 89.28(54)$ & $308.76^{\mathrm{b}} \pm 7.87(54)$ \\
Third parity and above & $2689.83^{\mathrm{b}} \pm 81.83(47)$ & $2726.08^{\mathrm{b}} \pm 96.50(47)$ & $284.11^{\mathrm{c}} \pm 8.51(47)$ \\
& & Season of calving & \\
Summer season & $2554.52 \pm 105.31(25)$ & $2650.25 \pm 124.18(25)$ & $310.45 \pm 10.95(25)$ \\
Rainy season & $2669.11 \pm 51.03(124)$ & $2748.99 \pm 60.18(124)$ & $302.24 \pm 5.30(124)$ \\
Winter season & $2586.03 \pm 66.70(65)$ & $2676.22 \pm 78.66(65)$ & $304.46 \pm 6.93(65)$ \\
\hline
\end{tabular}

Numbers in parenthesis indicate sample size under each class.

Means with the different superscripts in a column differs significantly. 
$266.6 \pm 55.15$ days, Ahmad (2008) as 260.42 \pm 1.35 days, Bashir et al. (2015) as $278 \pm 0.8$ days, Charlini and Sinniah (2015) as $238 \pm 78.8$ days, and Chaudhary (2015) as 295.90 13.94 days in Nili-Ravi buffaloes. Higher estimates of average service period than present study were obtained by Ahmad (2008) as $340.57 \pm 61.70$ days, and Hussain et al. (2006) as $369.53 \pm 8.44$ days in Nili-Ravi buffaloes.

Parity had significant effect $(\mathrm{p}<0.05)$ on lactation length. The longest lactation length was observed in the first parity (324.28 \pm 5.98 days) and the shortest lactation length in the present study has been observed in the third and above parity (284.11 \pm 8.51 days). Significant influence of parity on lactation length was reported by Chaudhry (1992). Afzal et al. (2007) and Bashir et al. (2015) reported non-significant effect of parity on lactation length in Nili-Ravi buffaloes.

Season of calving had non-significant effect on lactation length in the present study. The overall least-squares mean for lactation length in Nili-Ravi buffalo for summer, rainy, and winter season was estimated as $310.45 \pm 10.95$ days, $302.24 \pm 5.30$ days, and $304.46 \pm 6.93$ days, respectively. Naqvi and Shami (1999) in late maturing Nili-Ravi group and Bashir et al. (2015) in Nili-Ravi buffaloes reported that significant influence of season of calving on lactation length while non-significant effect on lactation length was reported by Khan and Chaudhry (2000) and Afzal et al. (2007), in Nili-Ravi buffaloes of Pakistan.

\section{Age at service}

The overall least squares mean of age at service calving in NiliRavi buffalo was estimated as $1418.76 \pm 16.60$ days (Table 4$)$. Parity had significant effect $(\mathrm{p}<0.05)$ on age at service. The least-squares mean for age at service for first parity, second parity and third and above parity was estimated as $881.94 \pm 20.03$ days, $1404.31 \pm 26.37$ days, and 1970.01 \pm 28.51 days, respectively. Season of calving had non-significant effect on age at service. The leastsquares mean for age at service in Nili-Ravi buffalo for summer, rainy, and winter season was estimated as $1412.81 \pm 36.68$ days, $1411.39 \pm 17.78$ days, and $1432.07 \pm 23.23$ days, respectively.

\section{Age at calving}

This trait is most important for dairy economics and can be defined as the period between the date of birth and date of first calving of animals. The age at first calving has a direct bearing on the lifetime performance of buffaloes. Early first calving reduces the cost of rearing the heifer and generation interval generates the first lactation record earlier as well, thereby helping early selection and consequently increasing the genetic gain. The overall average age at calving in Nili-Ravi buffalo was estimated as $1741.30 \pm 18.52$ days (Table 4).

Parity had significant effect $(\mathrm{p}<0.05)$ on age at calving. The leastsquares mean for age at calving for first parity, second parity and third and above parity was estimated as $1243.59 \pm 22.49$ days, $1711.45 \pm 29.42$ days, and $2268.85 \pm 31.80$ days, respectively. Higher estimates of average age at calving in the first parity than present study were obtained by Naqvi and Shami (1999) as $1291.31 \pm 8.68$ days in early maturing Nili-Ravi as well as $1308.78 \pm 16.44$ days in late maturing Nili-Ravi group, Hussain et al. (2006) as $1644.87 \pm 36.31$ days, Bashir et al. (2009) as $1685 \pm 9$ days, Charlini and Sinniah (2015) as 1347.46 \pm 118.321 days, and Chaudhary (2015) as $1327.16 \pm 12.09$ days in Nili-Ravi buffaloes.

Table 4 Least squares mean and standard error of different reproduction traits in Nili-Ravi buffalo reproduction traits

\begin{tabular}{llllll}
\hline Traits & Age at service & Age at calving & Service period & Calving interval & Dry period \\
\hline $\begin{array}{l}\text { Overall } \\
(\mu)\end{array}$ & $1418.76 \pm 16.60$ & $1741.30 \pm 18.52$ & $163.52 \pm 7.33$ & $466.55 \pm 6.70$ & $157.11 \pm 4.18$ \\
& $(214)$ & $(214)$ & $(214)$ & $(214)$ & $(214)$ \\
First parity & $881.94^{\mathrm{a}} \pm 20.03$ & $1243.59^{\mathrm{a}} \pm 22.49$ & $182.42^{\mathrm{a}} \pm 8.84$ & $483.84^{\mathrm{a}} \pm 8.08$ & $167.59^{\mathrm{a}} \pm 5.04$ \\
& $(113)$ & $(113)$ & $(113)$ & $(113)$ & $(113)$ \\
Second parity & $1404.31^{\mathrm{b}} \pm 26.37$ & $1711.45^{\mathrm{b}} \pm 29.42$ & $160.62^{\mathrm{b}} \pm 11.64$ & $464.69^{\mathrm{b}} \pm 10.64$ & $156.91^{\mathrm{b}} \pm 6.64$ \\
& $(54)$ & $(54)$ & $(54)$ & $(54)$ & $(54)$ \\
Third & $1970.01^{\mathrm{c}} \pm 28.51$ & $2268.85^{\mathrm{c}} \pm 31.80$ & $147.50^{\mathrm{c}} \pm 12.58$ & $451.13^{\mathrm{c}} \pm 11.50$ & $146.84^{\mathrm{c} \pm 7.17}$ \\
parity and above & $(47)$ & $(47)$ & $(47)$ & $(47)$ & $(47)$ \\
& & & Season of calving & \\
Summer season & $1412.81 \pm 36.68$ & $1727.33 \pm 40.92$ & $175.61 \pm 16.2$ & $472.34 \pm 14.80$ & $157.87^{\mathrm{a}} \pm 9.23$ \\
& $(25)$ & $(25)$ & $(25)$ & $(25)$ & $(25)$ \\
Rainy season & $1411.39 \pm 17.78$ & $1741.55 \pm 19.83$ & $154.42 \pm 7.85$ & $458.34 \pm 7.17$ & $148.26^{\mathrm{b}} \pm 4.47$ \\
& $(124)$ & $(124)$ & $(124)$ & $(124)$ & $(124)$ \\
Winter season & $1432.07 \pm 23.23$ & $1755.01 \pm 25.92$ & $160.52 \pm 10.26$ & $468.98 \pm 9.37$ & $165.21^{\mathrm{c}} \pm 5.85$ \\
& $(65)$ & $(65)$ & $(65)$ & $(65)$ & $(65)$ \\
\hline
\end{tabular}

Numbers in parenthesis indicate sample size under each class.

Means with the different superscripts in a column differs significantly. 
Season of calving had non-significant effect on age at calving. The least-squares mean for age at calving in Nili-Ravi buffalo for summer, rainy, and winter season was estimated as $1727.33 \pm 40.92$ days, $1741.55 \pm 19.83$ days, and $1755.01 \pm 25.92$ days, respectively. The present findings were in agreement with Nawle et al. 2012, who reported non-significant effect on calving age in Murrah buffalo.

\section{Service period}

It is the period between calving and subsequent conception. The service period is one of the principal factors causing variations in the calving interval, and thus influencing the breeding efficiency in dairy buffaloes. Generally, an optimum period of 60 days is allowed as postpartum rest. However, it is also essential to optimize the service period to ensure an optimum calving interval of 13 to 14 months. This period is not only a physiological function but also greatly depends on managerial practices like heat detection and artificial insemination. Shorter the service period greater the profit from reproductive efficiency and milk production point of view.

The overall least squares means of service period in Nili-Ravi buffalo was estimated as $163.52 \pm 7.33$ days (Table 4). Lower estimates of average service period than present study were obtained by Chaudhary (2015) as $150.78 \pm 16.53$ days. Higher estimates of average service period than present study were obtained by Pervez et al. (1994) as $215.12 \pm 4.99$ days and Hussain et al. (2006) as $208.35 \pm 24.03$ days.

Parity had significant effect $(\mathrm{p}<0.05)$ on service period. Short service period was observed in the third and above parity (147.50 \pm 12.58 days) and long service period was observed in the first parity (182.42 \pm 8.84 days). Naqvi, (2000) and Ali et al. (2011) reported that parity had significant effect on service period. While Hussain et al. (2006) reported that parity had non-significant effect on service period in Nili-Ravi buffaloes.

Season of calving had non-significant effect on service period in the present study. The least-squares mean for service period in Nili-Ravi buffalo for summer, rainy, and winter season was estimated as $175.61 \pm 16.20$ days, $154.42 \pm 7.85$ days, and $160.52 \pm 10.26$ days, respectively. Significant influence of season of calving on service period was reported by Naqvi and Shami (1999) in early maturing Nili-Ravi group, Naqvi (2000), Thevamanoharan, (2002), and Ali et al. (2011), while nonsignificant influence of season of calving on service period was reported by Naqvi and Shami (1999), and Hussain et al. (2006) late maturing Nili-Ravi group.

\section{Calving interval}

The calving interval is the period between two consecutive calving and comprises the service period. Since the gestation period is the least variable trait, the variation in calving interval leads to less number of calves in the lifetime and lower lifetime milk production, as well as the increased cost of replacement in the herd (Mahadevan, 1960). It is an index of reproduction and chiefly affected by lengths of the service period, lactation period, and dry period. Ideally, a minimum of 60 days of service period and 60 days of the dry period is essential for proper involution of the uterus and for proper growth of the foetus, respectively. However, if any of these periods is abnormally longer it would prolong the calving interval to an uneconomic level.

The overall least squares mean of calving interval in Nili-Ravi buffalo was estimated as $466.55 \pm 6.70$ days (Table 4). Lower estimates of calving interval than the present study were obtained by many workers. The overall least square mean for calving interval in Nili-Ravi buffalo were reported by and Pervez et al. (1994) as 520.27 \pm 2.58 days, Charlini and Sinniah (2015) as $412 \pm 91.6$ days, Chaudhary (2015) as $462.30 \pm 16.74$ days. Higher calving interval than the present study was reported by Khan and Akhtar (1999) as 467.10 11.58 days and Hussain et al. (2006) as $473.72 \pm 3.56$ days.

Parity had significant effect $(\mathrm{p}<0.05)$ on calving interval. The least-squares mean for calving interval for first parity, second parity and third and more than third parity was estimated as $483.84 \pm 8.08$ days, $464.69 \pm 10.64$ days, and $451.13 \pm 11.50$ days, respectively.

Season of calving had non-significant effect on calving interval in the present study. The overall least-squares mean for calving interval in Nili-Ravi buffalo for summer, rainy, and winter season was estimated as $472.34 \pm 14.80$ days, $458.34 \pm 7.17$ days, and $468.98 \pm 9.37$ days, respectively. Hussain et al. (2006) and Ghaffar et al. (1991) reported season of calving had non-significant effect on calving interval.

\section{Dry period}

The period between the dates of drying to date of next calving is termed as the dry period or dry days. The dry period is the period in which the animal has already experienced milk secretion phenomena but has ceased to produce milk due to the advanced stage of pregnancy or cessation of lactation due to other physiological reasons. This period is zero output period for the breeder, but it is the preparatory period for the mammary gland to produce in the lactations to come, after second or subsequent calving. An optimal 60 days of dry period is essential for the cow to build up her body resources for production in the next lactation.

The overall least squares means of dry period in Nili-Ravi buffalo was estimated as $157.11 \pm 4.18$ days (Table 4 ). Lower estimates of least squares mean dry period than present study were obtained by Chaudhary (2015) as $142.99 \pm 15.81$ days in Nili-Ravi buffaloes. Higher estimates of least squares mean dry period than present study were reported by Naqvi and Shami (1999) as $241.59 \pm 4.18$ days, $306.39 \pm 8.78$ in early and late maturing Nili-Ravi group, 
Hussain et al. (2006) as 194.4 \pm 12.37 days, Bashir et al. (2015) as $258 \pm 1.6$ days, and Charlini and Sinniah (2015) as $181 \pm 96.2$ days in Nili-Ravi buffaloes.

Parity had significant effect $(\mathrm{p}<0.05)$ on dry period. Short dry period was observed in the third and above parity $(146.84 \pm 7.17$ days) and long dry period was observed in the first parity. Bashir et al. (2015) reported that parity had significant effect on dry period.

Season of calving had significant effect $(\mathrm{p}<0.05)$ on dry period. Rainy season showed short dry period (148.26 \pm 4.47 days), whereas winter season showed long dry period (165.21 \pm 5.85 days). Significant effect of season of calving on dry period has been reported by Naqvi and Shami (1999), Bashir et al. 2015 in NiliRavi buffaloes. Ghaffar et al. (1991) reported that season calving had non-significant effect on dry period.

\section{Conclusions}

Number of pregnancies, parity, had shown a significant effect on all production and reproduction traits whereas season of calving effected dry period in Nili-Ravi buffaloes. The present study suggests that Nili-Ravi buffaloes perform best during their first two pregnancies and parity can be included as a criteria for selection of Nili-Ravi buffaloes having superior production and reproduction. Further studies are required to compare the production and reproduction performance between Murrah and Nili-Ravi buffalo breed. This will be useful for the farmers and breeders to identify the real genetic potential of the performance traits in the Nili-Ravi buffalo and shall help in management and conservation of this useful germplasm of Punjab state.

\section{Acknowledgements}

The authors duly acknowledge Director, ICAR-NDRI, Karnal, ICAR-NBAGR, Karnal and ICAR-CIRB, Hisar for providing funding and facilities to carry out this study. Technical support received from Dr. K.L. Mehrara, CTO, CIRB sub-campus (Nabha), is thankfully acknowledged.

\section{References}

Afzal M, Mirza MA (2007). Some factors affecting milk yield and lactation length in Nili-Ravi buffaloes. Pakistan Vet J 27: 113-117

Ahmad M (2008). Estimated breeding values and genetic trend for 305day milk yield in buffalo herd at les Chak Katora. Pakistan J Agric Sci 45: 212-214

Ali A, Javed K, Ahmad N, Rehman S (2011) Environmentl factors affecting some reproductive traits in Nili Ravi buffaloes. J Anim Plant Sci 21: $868-871$

Bashir M, Khan M, Lateef M, Mustafa MI, Khalid MF, Ur-rehman S, Farooq U (2015) Environmental factors affecting productive traits and their trends in Nili-Ravi buffaloes. Pakistan J Life Social Sci 13: $137-144$

Christa Charlini B, Sinniah J (2015) Performance of Murrah, Surti, NiliRavi buffaloes and their crosses in the intermediate zone of Sri
Lanka. Livest Res Rural Dev 27, Article \#47. Retrieved August 17, 2020, from http://www.lrrd.org/lrrd27/3/char27047.html

Chaudhary M (2015) Genetic studies on production, fertility and longevity traits in Murrah and Nili-Ravi Buffaloes. Ph.D. thesis submitted to LUVAS, Hissar

Cunha RPL, Molina LR, Carvalho AU (2008) Subclinical mastitis and the relationship between somatic cell count with number of lactations, production and chemical composition of the milk. Arq Bras Med Vet Zootec 60: 19-24

Ghaffar A, Khan MI, Mirza MA, Pirzada WH (1991) Effect of year and calving season on some traits of economic importance in Nili-Ravi buffaloes. Pakistan J Agric Res 12: 217-221

Harvey WR (1990) User's Guide for LSMLMW and MIXMDL. PC-2 Version. Mixed Model Least Squares and Maximum Likelihood Computer Program. Ohio State University, Columbus, USA

Hussain Z, Javed K, Hussain SMI, Kiyani GS (2006) Some environmental effects on productive performance of Nili-Ravi buffaloes in Azad Kashmir. J Anim Plant Sci 16: 66-69

Khan M, Chaudhary H (2000) Lactation length and its behavior in NiliRavi buffaloes. Pakistan Vet J 20: 81-84

Khan M, Hassan F, Saif M, Rehman U, Hyder A, Bajwa I (2007) Genetic control of milk yield from lactations of different duration in NiliRavi buffaloes. Archiv Fur Tierzucht 50

Khan RN and Akhtar S (1999). Production Characteristics of Nili-Ravi Buffaloes. Asian-Aus. J Anim Sci 12: 56-60

Kramer YC (1957) Extension of multiple range tests to group correlated adjusted means. Biometrics 13: 13-18

Mahadevan P (1960). Some genetic parameters of the water buffalo. Empire J Exp Agric 28: 99-103

Manzoor A, Maqsood A and Naz NA (2003). Environmental and genetic factors affecting first lactation milk yield, peak milk yield and persistency of lactation in Nili-Ravi buffaloes. Pakistan J Vet Res 1: 20-24

Naqvi AN and Shami SA (1999). Comparative Performance of Early and Late Maturing Nili Ravi Buffalo Heifers. Asian-Australas J Anim Sci 12: $336-340$

Naqvi AUN (2000) Effect of Parity and Season of Calving on Service Period in Nili Ravi Buffalo in Pakistan. Asian-Australas J Anim Sci 13: $287-291$

Nawale VS, Chakravarty AK, Chakraborty D, Vohra V (2012) Non-genetic factors affecting reproductive traits in Murrah buffaloes. Indian Vet J 89: 18-19

Pervez A, Muhammad AK, Zaheer A and Sadaqat HH (1994). Inheritance of some reproductive traits in Nili-Ravi buffaloes. Buffalo Bull 13: 13-17

Price T, Schluter D (1991) On the low heritability of life history traits. Evolution 45: 853-861

Thevamanoharan K, Vandepitte W and Mohiuddin G (2002) Heritability estimates for various performance traits of Nili-Ravi buffaloes. In Proc. $7^{\text {th }}$ World Cong. Genet Appl Livest Prod pp, 1-4

Vij PK, Tantia M (2005). Status of Nili Ravi buffaloes in India. Ani Genet Resour Inf 37 